\title{
PHYSICAL AND CHEMICAL PARAMETERS IMPACT ON EOSIN SPECTRAL DETERMINATIONS
}

\author{
Liljana Kola \\ University of Tirana, Faculty of Natural Sciences, \\ Center of Applied Nuclear Physics, P.O. Box 85, Tirana, Albania \\ kolaliljana@yahoo.it
}

\begin{abstract}
The fluorescence ability of eosin enables its using as an artificial tracer in the water system studies. The problem deals with the application of eosin to trace and determine water movements within the karstic system and underground waters. The fluorescence intensity of fluorescent dyes in water samples depends on their physical and chemical properties, such as $\mathrm{pH}$, temperature, presence of oxidants, etc. Besides that, the UV radiation may induce photochemical decomposition of eosin which can cause large measurement errors. This paper presents the taken results studying the influence of these factors on eosin fluorescence intensity using the concentration and synchron scan methods. The method we have elaborated for this purpose made it possible to optimize procedures we use to analyze water samples for the presence of eosin and measure its content, even in trace levels by the means of the Perkin Elmer LS 55 Luminescence Spectrometer
\end{abstract}

Key words: spectral determination; eosin; fluorescence intensity $\left(I_{F}\right)$; synchron scan; artificial tracer

\section{ВЛИЈАНИЕ НА ФИЗИЧКИТЕ И ХЕМИСКИТЕ ПАРАМЕТРИ ВРЗ СПЕКТРАЛНОТО ОПРЕДЕЛУВАЊЕ НА ЕОЗИН}

\begin{abstract}
Флуоресцентната карактеристика на еозинот овозможува негова употреба како вештачки обележувач во студиите за водните системи. Оваа карактеристика се користи за следење и одредување на движењето на водата низ карсните предели и низ подземните текови. Интензитетот на флуоресценција на флуоресцентните бои во примероци на вода зависи од нивни физички и хемиски својства:: $\mathrm{pH}$, температура, присуство на оксиданси итн. Освен тоа, УВ зрачењето може да индуцира фотохемиско распаѓање на еозинот, што може да доведе до големи грешки при негово мерење. Во овој труд се презентирани резултатите добиени со проучување на влијанието на споменатите фактори врз флуоресцентниот интензитет на еозин со користење на концентрациски и синхотронски скенирачки методи. Постапката која е образложена овозможува да се оптимираат користените постапки за анализа на примероци вода во присуство на еозин. Содржината на еозин може да се определи дури и при негово присуство во траги, како што овде е направено со користење на луминисцентен спектрометар од типот Perkin Elmer LS 55.
\end{abstract}

Клучни зборови: спектрално определување; еозин; флуоресцентен интензитет $\left(I_{F}\right)$; синхотронски скен; вештачки обележувач

\section{INTRODUCTION}

The management of aquatic systems requires one to know and study them in order to assess their water usability as well as to find optimum and sustainable ways of water management $[1,2]$.

Modern and powerful techniques of tracers in hydrology are elaborated for this purpose. The in- troduction of fluorescent and radioactive tracers has led to enormous methodological and instrumental developments $[1,2]$. The problems they deal with when applied in studying various water systems might be grouped into different groups, according to WHERE the groundwater is flowing to, FROM WHERE it comes, WHETHER underground hydraulic connections exist between dif- 
ferent points of the system or not, HOW the groundwater is flowing in(to) and/or through the system under the study, etc. [3].

The application of the spectrofluorometric technique in our Institute refers mainly to the study of water systems by using fluorescent dyes as artificial tracers. System's water is labelled through them according to some present plans and objectives and then their presence is monitored from time to time in various parts of the system under the study. This information can be obtained by measuring the content of fluorescent dyes in direct, water samples or in active coal samples. In this paper we will present only the eosin results obtained from the experiments in water samples.

Eosin $-\mathrm{C}_{20} \mathrm{H}_{6} \mathrm{Br}_{4} \mathrm{Na}_{2} \mathrm{O}_{5}$ is produced from the reaction of the fluoresceine and Bromine [3, 4].

It is an anionic tracer not dangerous for the people, so we can use it in the study of water systems.

When measured in water samples eosin fluorescence intensity depends on different physical and chemical properties of the sample matrix $-\mathrm{pH}$, temperature, oxidants' presence, etc. $[3,4,5]$.

Their respective influence should be studied by our Perkin Elmer LS 55 Luminescence Spectrometer in order to determine optimal conditions for detecting the eosin maxima in trace levels.

\section{EXPERIMENTAL}

The fluorescence of some water containing eosin is measured by means of the Perkin-Elmer spectral fluorometer LS 55. We have previously analyzed some "blanks" having been sampled from different water systems, in order to assess the natural presence of "eosin" fluorescence, the so called "background".

A special software package (FL WinLab) manages different application programs the instrument LS 55 offers. We have detected and measured tracer contents in water samples by using the Synchronous Scan and Concentration Applications. First the instrument validation should be realized through the Raman spectra (Raman Peak Wavelength, Raman Peak Intensity and Raman S/N ratio) from a sealed water cell [6] and a reference material (Anthracene) [7]. Then the instrument stability is checked with regard to the fluorescence intensity by means of a reference material (Anthracene) $[5,7]$. Parameters were set in order to inves- tigate the eosin content in water samples through synchronous and concentration applications. These parameters were as follows: Excitation wavelength $-516 \mathrm{~nm}$; Emission wavelength - $538 \mathrm{~nm}$; Excitation slit $-10.0 \mathrm{~nm}$; Emission slit - $10.0 \mathrm{~nm}$; Delta lambda - $21 \mathrm{~nm}$; Auto Background Subtract, etc.

The characteristic peak wavelengths were verified beforehand by some preliminary synchronous scans.

\section{RESULTS AND DISCUSSION}

At first the instrument was previously calibrated with six eosin standard solutions by means of the calibration application for eosin determinations. The equation of the eosin calibration curve was:

$$
\begin{gathered}
I_{F}=43.915 * \mathrm{C}+0.019 \\
R^{2}=0.9999
\end{gathered}
$$

where:

$I$ - the fluorescence intensity

$C$ - eosin concentration (ppb)

$R^{2}$ - the correlation coefficient

\section{The influence of $\mathrm{pH}$ values on the eosin fluorescence}

First, a measurement of the $\mathrm{pH}$ of the eosin standard solution and the respective fluorescence intensity in normal conditions was undertaken. Then the $\mathrm{pH}$ value was changed by adding $\mathrm{HCl}$ $0.05 \mathrm{~mol} / \mathrm{dm}^{-3}$ through a micropipette, in order to create an acid medium, as well as EDTA-Na $0.05 \mathrm{~mol} / \mathrm{dm}^{-3}$, in order to create a basic medium. After each additional portion of the acid or basic solutions, the respective fluorescence of the sample was measured. The obtained results are shown in the following diagram (Fig. 1).

Figure 1 shows clearly the highest and the most stable values of the eosin fluorescence intensity which belong to $\mathrm{pH}$ values exceeding 5.58. Lower than $\mathrm{pH}=5.58$ intensity declines very fast. The eosin fluorescence intensity is considerably reduced when $\mathrm{pH}$ values of the sample are lowered below 5.58, reaching $5.84 \%$ of its initial value for $\mathrm{pH}=0.4$. All this means in practice each time one is going to measure the water sample for the eosin presence can do it directly but in order to have correct measurements of the eosin content the sample 
matrix must be controlled before that $\mathrm{pH}>5.6$. The influence of $\mathrm{pH}$ on the eosin fluorescence intensity is a reversible process.

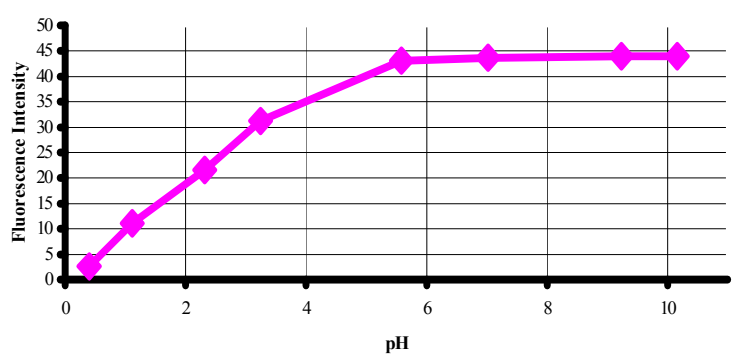

Fig. 1. Influence of $\mathrm{pH}$ on eosin fluorescence intensity

\section{The influence of temperature on the eosin fluorescence intensity}

When sample temperature is increased the excited molecules spend more energy in rotational and vibrational movements, which leads to heat production. It is expected therefore to measure lower fluorescence intensities $[4,5]$. The temperature influence on fluorescence intensity of different dye tracers might be manifested differently. This phenomenon for the case of eosin has been studied.

First, the temperature and fluorescence intensity of the standard solution of $1 \mathrm{ppb}$ eosin for normal conditions have been measured (the bold values in Table 1) and then we have changed temperature and measured respective fluorescence intensities. Table 1 shows the measurement results.

Table 1

Influence of temperature on intensity of eosin

\begin{tabular}{cccc}
\hline \hline No & $\begin{array}{c}\text { Temperature } \\
{ }^{\circ} \mathrm{C}\end{array}$ & Intensity & $\begin{array}{c}\text { Conc. } \\
\mathrm{ppb}\end{array}$ \\
\hline 1. & 10.1 & 43.951 & 1.001 \\
2. & 12.9 & 43.461 & 0.989 \\
3. & 16.4 & 43.272 & 1.002 \\
4. & $\mathbf{2 0 . 5}$ & $\mathbf{4 3 . 9 6 8}$ & $\mathbf{1 . 0 0 1}$ \\
5. & 26.7 & 43.441 & 0.989 \\
6. & 29.8 & 43.756 & 0.996 \\
7. & 32.0 & 43.555 & 0.991 \\
8. & 37.9 & 43.671 & 0.994 \\
9. & 41.0 & 43.784 & 0.996 \\
\hline \hline
\end{tabular}

The measurement results demonstrate clearly that the eosin fluorescence is stable if temperature values of the water sample change from 10 to $41{ }^{\circ} \mathrm{C}$.

\section{The Influence of oxidants on eosin fluorescence intensity.}

The fluorescence ability could be irreversibly destroyed following the action of oxidants, such as ozone, chloride, etc, on fluorescent substances.

Having this in view, we have focused our study on investigating the influence of the sodium hypochlorite on the eosin fluorescence intensity because it is usually used as a disinfectant in drinking water supply in our country. We have first measured the fluorescence intensity in the standard solution of $0.05 \mathrm{ppb}$ eosin having no oxidizing agents. We have had equal amount of solution of $0.05 \mathrm{ppb}$ eosin in eight flasks. Then we have added different portions of $\mathrm{NaOCl}$ in every flask: 100, 200, 300, 400, 500, 700, $900 \mu \mathrm{l}$ and measured respective values of the eosin fluorescence intensity. The obtained results demonstrate clearly the destructive effect of oxidizing agents on the eosin fluorescence in the water samples (Fig. 2).

Figure 2 shows plainly this effect. The first portion of the oxidizing substance added to an eosin sample decreased its fluorescence by $14.38 \%$ of its initial intensity; $500 \mu \mathrm{l}$ of oxidizing agent in the same sample reduces fluorescence to $50 \%$ of its initial value whereas $700 \mu$ of $\mathrm{NaOCl}$ reduces fluorescence to $76.45 \%$ of its initial value. That means the oxidants destroy vigorously and irreversibly the fluorescent capacities of eosin.

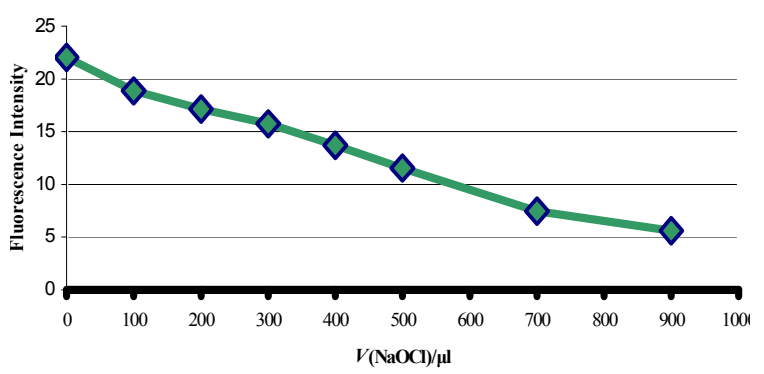

Fig. 2. Decay of eosin fluorescence in water solutions containing sodium hypochlorite

Further measurements carried out on this effect have shown that the fluorescence intensity is reduced in larger proportions when longer time periods of the oxidants presence in the samples are applied. The data in Table 2 are obtained by meas- 
uring the fluorescence intensity in different moments after having added sodium hypochlorite to the sample.

Table 2

The value of the $I_{F}$ in different moments after having added $\mathrm{NaOCl}$ to the sample

\begin{tabular}{|c|c|c|c|c|}
\hline $\begin{array}{l}\text { Eosin st. sol. + } \\
\mathrm{NaOCl} \text { (ox.) }\end{array}$ & $\begin{aligned} & I_{F} \\
t= & 0 \text { min }\end{aligned}$ & $\begin{array}{c}I_{\mathrm{F}} \\
t=30 \mathrm{~min}\end{array}$ & $\begin{array}{c}I_{\mathrm{F}} \\
t=60 \mathrm{~min}\end{array}$ & $\begin{array}{c}I_{\mathrm{F}} \\
t=90 \mathrm{~min}\end{array}$ \\
\hline $\mathrm{E}+0 \mu \mathrm{lOx}$ & 22.021 & 22.021 & 22.021 & 22.021 \\
\hline $\mathrm{E}+100 \mu \mathrm{l} \mathrm{Ox}$ & 18.862 & 12.832 & 8.576 & 4.906 \\
\hline $\mathrm{E}+200 \mu 1 \mathrm{Ox}$ & 17.146 & 8.971 & 4.687 & 2.388 \\
\hline $\mathrm{E}+300 \mu 1 \mathrm{Ox}$ & 15.755 & 4.922 & 1.795 & 0.676 \\
\hline $\mathrm{E}+400 \mu \mathrm{l}$ Ox. & 13.676 & 2.584 & 0.720 & 0.387 \\
\hline $\mathrm{E}+500 \mu \mathrm{l} \mathrm{Ox}$ & 11.547 & 1.360 & 0.552 & 0.264 \\
\hline $\mathrm{E}+700 \mu \mathrm{l} \mathrm{Ox}$ & 7.442 & 0.680 & 0.374 & 0.231 \\
\hline $\mathrm{E}+900 \mu \mathrm{l} O \mathrm{x}$ & 5.612 & 0.530 & 0.252 & 0.135 \\
\hline $\mathrm{E}+1000 \mu \mathrm{l}$ Ox. & 5.118 & 0.473 & 0.244 & 0.135 \\
\hline
\end{tabular}

So, in the flask containing eosin standard solution and $100 \mu \mathrm{l} \mathrm{NaOCl}$, only $68 \%$ of the initial fluorescence has remained in it 30 minutes later while this number is lowered to $45.5 \%$ after 60 minutes and to $26 \%$ after 90 minutes. In the last flask containing eosin standard solution and 1000 $\mu \mathrm{NaOCl}$, only $9.24 \%$ of the initial fluorescence has remained in it 30 minutes later, while this value is lowered to $4.8 \%$ after 60 minutes. Later, after 90 minutes $97.4 \%$ of the eosin initial fluorescence was destroyed.

That means the time factor should be kept always in view when working with water samples containing oxidants in studies using eosin as an artificial tracer.

\section{The influence of the UV radiation on the eosin fluorescence intensity}

The UV radiation may induce photochemical decomposition of eosin which can cause large measurement errors. To investigate this phenomenon, an eosin standard solution was prepared (conc. $=1 \mathrm{ppb}$, solvent: distilled water) and added in 2 colorless glass bottles and in 2 brown colored bottles. Then, they were put in two different situations so-called: 'in the light' and 'in the shadow'. One colorless glass bottle and one brown colored glass bottle were firstly put in the "in the light" and the other uncolored bottle and afterwards one brown colored one was put 'in the shadow'. The eosin fluorescence intensities of these four flasks were measured at the same time according to one schedule. At the beginning the measurements were frequent and after some times were less than before.

The supervision of this process continued for four months. The obtained results of the eosin photodecomposition in different conditions are shown in the following Tables and diagrams. Table 3 shows the decay of the fluorescence of eosin standard solution of $1 \mathrm{ppb}$ in the colorless glass bottles exposed to daylight in the condition of so called 'in light'.

Table 3

Decay of the fluorescence of eosin aqueous solutions in colorless glass bottles, 'in light'

\begin{tabular}{cccccc}
\hline \hline No Exposition to & $I_{F}$ of \\
daylight (day) & eosin & $\begin{array}{c}\text { Eosin } \\
\text { conc. } \\
\text { (ppb) }\end{array}$ & $\begin{array}{c}\text { Day of the } \\
\text { measurement }\end{array}$ & $\begin{array}{c}\text { Time of the } \\
\text { measurement }\end{array}$ \\
\hline 1. & 0 & 43.724 & 0.995 & 12.03 .07 & $12: 00$ \\
2. & 0.96 & 0.791 & 0.017 & 13.03 .07 & $11: 30$ \\
3. & 2.96 & 0.019 & 0.00 & 15.03 .07 & $11: 30$ \\
4 & 3.92 & 0.00 & 0.00 & 16.03 .07 & $10: 30$ \\
\hline \hline
\end{tabular}

Table 3 shows how a $1 \mathrm{ppb}$ eosin standard solution in colorless bottle decomposes when subjected to daylight. It is obvious from the results that the UV radiation decay immediately eosin. Light destroys $98.29 \%$ of the total fluorescence intensity only after one day, whereas after two days exposure, the eosin fluorescence was destroyed $100 \%$.

Table 4 shows the results of the eosin fluorescence intensity $\left(I_{F}\right)$ decay after exposure to daylight in the brown glass flask, 'in light'.

One can see clearly from the results of Table 4 that the fluorescence intensity of eosin after 3 days exposure to daylight in the brown glass flask, 'in light' is destroyed $91.53 \%$ and completely after 42 days, so 39 days later than in the case of the colorless bottle in the same conditions. This proves that the brown flask delays the decomposition of eosin. 
Table 4

Decay of the fluorescence intensity $\left(I_{F}\right)$ of eosin in the brown glass flask, 'in light'

\begin{tabular}{cccc}
\hline \hline No & $\begin{array}{c}\text { Exposition to daylight } \\
\text { (day) }\end{array}$ & $\begin{array}{c}I_{F} \\
\text { of eosin }\end{array}$ & $\begin{array}{c}\text { Eosin conc. } \\
\text { (ppb) }\end{array}$ \\
\hline 1. & 0 & 43.724 & 0.995 \\
2. & 0.96 & 28.565 & 0.680 \\
3. & 2.96 & 3.704 & 0.084 \\
4. & 3.92 & 2.527 & 0.057 \\
5. & 6.92 & 0.245 & 0.005 \\
6. & 7.92 & 0.243 & 0.004 \\
7. & 8.92 & 0.195 & 0.004 \\
8. & 10.92 & 0.192 & 0.004 \\
9. & 13.92 & 0.187 & 0.004 \\
10. & 14.92 & 0.178 & 0.003 \\
11. & 15.92 & 0.157 & 0.003 \\
12. & 16.92 & 0.151 & 0.003 \\
13. & 17.92 & 0.086 & 0.002 \\
14. & 20.92 & 0.060 & 0.001 \\
15. & 37.92 & 0.030 & 0.001 \\
16. & 42.92 & 0.00 & 0.00 \\
17. & 50.92 & 0.00 & 0.00 \\
\hline \hline
\end{tabular}

The obtained results of the eosin fluorescence intensity $\left(I_{F}\right)$ decay after exposure to daylight in colorless glass bottle, 'in shadow' are shown in Table 5 .

Table 5

Decay of the eosin fluorescence Intensity in the colorless glass bottle, 'in shadow'

\begin{tabular}{cccc}
\hline \hline No & $\begin{array}{c}I_{F} \\
\text { of eosin }\end{array}$ & $\begin{array}{c}\text { Eosin conc. } \\
(\mathrm{ppb})\end{array}$ & $\begin{array}{c}\text { Exposition to daylight } \\
\text { (day) }\end{array}$ \\
\hline 1. & 43.724 & 0.995 & 0 \\
2. & 2.655 & 0.060 & 0.96 \\
3. & 0.234 & 0.005 & 2.96 \\
4. & 0.00 & 0.000 & 3.92 \\
\hline \hline
\end{tabular}

The results above show the eosin fluorescence intensity how a $1 \mathrm{ppb}$ eosin standard solution in a colorless bottle decomposes when subjected to daylight. It is clear from the results that the UV radiation decays immediately eosin in this case, too. Light destroys $93.93 \%$ of the total fluo- rescence intensity only after one day. The UV radiation destroyed $100 \%$ of the eosin fluorescence after three days exposure, so one day later than in the case of the colorless bottle 'in light' (Tab. 3).

Table 6 shows the obtained results after exposure to daylight of $1 \mathrm{ppb}$ eosin standard solution in a brown flask in condition 'in shadow'.

Table 6

Decay of the eosin fluorescence intensity in the brown glass flask, 'in shadow'

\begin{tabular}{cccc}
\hline \hline No & $\begin{array}{c}I_{F} \\
\text { of eosin }\end{array}$ & $\begin{array}{c}\text { Eosin conc } \\
(\mathrm{ppb})\end{array}$ & $\begin{array}{c}\text { Exposition to } \\
\text { daylight (day) }\end{array}$ \\
\hline 1. & 43.724 & 0.995 & 0 \\
2. & 41.013 & 0.933 & 0.96 \\
3. & 36.942 & 0.845 & 2.96 \\
4. & 35.456 & 0.807 & 3.92 \\
5. & 29.436 & 0.671 & 6.92 \\
6. & 29.072 & 0.662 & 7.92 \\
7. & 28.432 & 0.647 & 8.92 \\
8. & 26.056 & 0.593 & 10.92 \\
9. & 24.009 & 0.546 & 13.92 \\
10. & 23.346 & 0.531 & 14.92 \\
11. & 22.628 & 0.515 & 15.92 \\
12. & 22.051 & 0.502 & 16.92 \\
13. & 20.550 & 0.468 & 17.92 \\
14. & 17.385 & 0.395 & 20.92 \\
15. & 6.344 & 0.144 & 37.92 \\
16. & 6.242 & 0.142 & 42.92 \\
17. & 6.150 & 0.140 & 50.92 \\
18. & 6.066 & 0.138 & 59.92 \\
\hline \hline & & & \\
\hline
\end{tabular}

The results of Table 6 show clearly that the decay of the eosin fluorescence intensity in the brown glass flask, 'in shadow' is more gradual than the decay in the other conditions. In this case, light destroys $86.3 \%$ of the eosin total fluorescence intensity only after 60 days.

Figure 3 shows the dynamics of the eosin decomposition after exposure to daylight in four different conditions mentioned above.

It is obvious from the graphs that the brown glass and especially the brown flask delays the decomposition of eosin. 


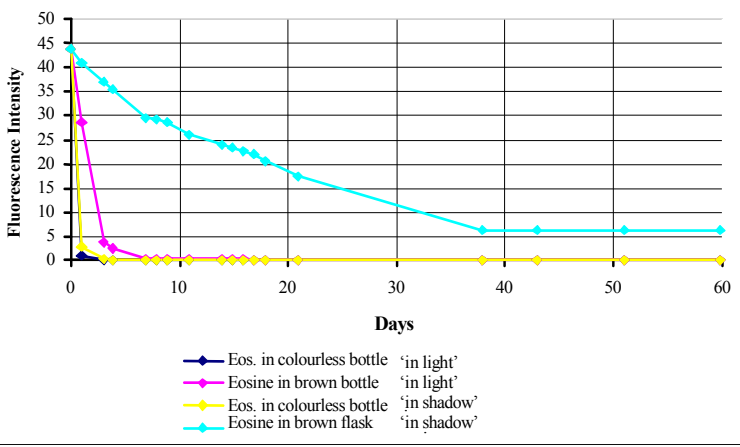

Fig. 3. Decay of the fluorescence of eosin in aqueous solutions exposed to different conditions of daylight

The results show clearly that eosin is extremely sensible to daylight. It can decay very quickly. That means one must have this influence in consideration when one wants to use eosin as an artificial tracer for water system studies. It should therefore not be used in surface water tracing experiments but only in underground water studies.

\section{CONCLUSIONS}

- The maximal fluorescence of eosin in the aqueous solution is reached at the $\mathrm{pH}$-value over 5.58. The fluorescence intensity of eosin decreases sensibly for $\mathrm{pH}<5.58$, but one can measure the eosin fluorescence intensity directly in water samples because their $\mathrm{pH}$-values are usually over 6 . Anyway one should check $\mathrm{pH}$ of water samples before eosin fluorescence measurements.

- One can observe that the eosin fluorescence intensity doesn't change for temperature different values from 10 to $40^{\circ} \mathrm{C}$. That means special treatments should not be applied to the water samples and standards before eosin measuring.

- The oxidants destroy strongly and irreversibly the fluorescent capacities of eosin. This quenching effect on the eosin fluorescence is intensified when the concentration of oxidants in water samples arises and the contact time of eosin to such agents is longer, too.

For this reason, water must not be sampled from water supply network or it should be previously analyzed for probable presence of oxidants, then to decide whether to choose sampling points thereof. Otherwise the fluorescence measurements of such water samples could lead very probably to erroneous results.

- The UV radiation induces a photochemical decomposition which leads to analytical errors and the destruction of eosin in the aqueous solution. That's why it is necessary to protect eosin standards and samples from the ambient light by storing them in brown glass and in the dark.

- Eosin is more affected by the ambient light than some other dyes and can decay very quickly. It should therefore not be used in surface water tracing experiments.

\section{REFERENCES}

[1]. H. Behrens, Tracer Methods in Isotope Hydrology, IAEA, Vienna, 1983.

[2]. H. Behrens, Water Tracer Chemistry - Factor Determining Performance and Analytics of Tracers; $5^{\text {th }}$ Int. Symp. on Underground Water Tracing, Athens, 1986, pp. 121133.

[3]. W. Käss, Tracing Technique in Geohydrology, Berlin, 1994.

[4]. R. Benischke, Fluorescent Tracers in Hydrology, Graz, 1991.

[5]. L. Kola, Optimization of Fluorometric Determinations in Water Samples and Active Coal Samples (Albanian Printing), Ph.D. Thesis, Tirana University, 2008.

[6]. Perkin Elmer, Molecular Spectroscopy, LS 55 User's Guide, Buckinghamshire, UK, 2000.

[7]. Perkin Elmer, Fluorescence Intensity Samples, C5207440, Booklet, 2000. 